\title{
SUSTAINED CHARACTER BUILDING THROUGH LITERATURE FOR COLLEGE STUDENTS IN INDONESIA
}

\author{
Tatit Hariyanti \\ Faculty of Humanities, University of Technology Yogyakarta - Indonesia \\ E-mail: tatit03fib@gmail.com \\ and \\ Sudjito \\ Faculty of Law, University of Gadjah Mada Yogyakarta - Indonesia \\ E-mail: sudjito_fh_ugm@yahoo.com
}

\begin{abstract}
This article aims at promoting sustained character building through literature especially for college students in Indonesia. Till present, the character building has been restricted to the embedment of good virtues to children and adolescents. The majority of existing studies and researches, therefore, tend to focus their attention on such limited area. Character building ought to be a sustainable effort halted not when one finishes his/her study at elementary or intermediate grades. It should be maintained all life long. There are two highlighted problems which are going to explore in this paper: first, why literature is still considered to be one of the effective media to establish sustained character building for college students and second, what appropriate Instructional Strategies to conduct such effort are. The result shows that literature is still effective due to its natural characteristics, its wide spectrum, and its dynamically broadened functions. Under the conviction that the students have already been undergoing the process of embedment of some core values before, the given literary works containing, elaborating and questioning or challenging the given embedded values are taken to be the source of discussion. The instructional strategies cover discussion, debate, seminar, film appreciation, and creative writing.
\end{abstract}

Keywords: character building, instructional strategies, literature, sustained

\begin{abstract}
Abstrak
Artikel ini bertujuan untuk mempromosikan pembangunan karakter berkelanjutan melalui literatur khususnya mahasiswa di Indonesia. Sampai saat ini, pembangunan karakter telah dibatasi dengan menanamkan kebajikan yang baik kepada anak-anak dan remaja. Mayoritas kajian dan penelitian yang ada, cenderung memusatkan perhatian pada area terbatas tersebut. Membangun karakter seharusnya menjadi sebuah upaya berkelanjutan yang dihentikan bila orang telah menyelesaikan studi pada tingkat dasar atau menengah. Itu harus dijaga sepanjang hidup. Ada dua masalah yang akan dibahas dalam artikel ini: pertama, mengapa kesusasteran masih dianggap sebagai salah satu media efektif untuk membangun karakter yang berkelanjutan bagi mahasiswa; dan kedua, strategi instruksional apa yang tepat untuk melakukan upaya tersebut. Hasilnya menunjukkan bahwa kesusasteraan masih efektif karena karakteristik alaminya, spektrumnya yang luas, dan fungsi yang diperluas secara dinamis. Di bawah keyakinan bahwa orang-orang tua telah menjalani proses penyematan beberapa nilai inti sebelumnya, karya sastra yang diberika mengandung, merinci dan mempertanyakan atau menantang nilai-nilai tertanam yang diberikan dianggap sebagai sumber diskusi. Strategi instruksional mencakup diskusi, debat, seminar, apresiasi film, dan penulisan kreatif.
\end{abstract}

Kata kunci: pembangunan karakter, strategi instruksional, kesusasteraan, berkelanjutan

\section{Introduction}

Since the last decades, character building and character education have been regaining its popularity all over the world. Violence at schools, mass fighting, disrespect, general lack of manners, and bullying have grown and been easily seen in our daily life and shown through mass media all over the world. Parents blamed on the schools and educators for violating the principle of education pursuing only their own 
material benefits; educators believed it could be resulted from a lack of values being taught at home. As observed by Lickona many adverse social changes have occurred in these areas: (a) the retreat of educators from their roles as character education instruction; (b) the breakdown of many families; (c) the lack of religious upbringing. Likewise, contributing to the problem are the unsuitable peer culture influences through television, advertising and internet. ${ }^{1}$

Resulting industrialization from which arises technological advancement there emerges the shifting of values in societies and families as well, providing availability of choices which may be different from the ones they used to be familiar. There are many things that could ruin the embedded values outside of the walls of families and schools. While distinguishing one another, character itself is subject to change influenced by physical and social environment. Castells points out that the kinds of disorientation brought on the presence of the 'cyber world' in form of pornography, abusive messages, insults, strange cultures, etc. pose the most serious challenge to moral education, regardless of its sites of application. ${ }^{2}$ Similarly Damon, asserts the emergence of information communication technology with a plethora of information and ideas being disseminated instantly has altered the educational landscape of

T. Lickona, 1991, Educating for character: How our schools can teach respect and responsibility. New York: Bantam Books, or look at in: T. Lickona, "A Comprehensive Approach to Character Building in Catholic Schools", Catholic Education: A Hournal of Inquiry and Practice, Vol 1 Issue 2, July 2013; Jamie Marshall, 2006, Character Education Instruction Integrated Through Literature in Elementary Classrooms. All Regis University Theses. Paper 408, p. 2. Retrieved on 27 February, 2017 from http://epublications.regis.edu/theses; see also E. Y. Washington, M.A. Clark, and A.L. Dixon, "Everyone in School Should Be Involved" Preservice Counselors' Perceptions of Democracy and the Connections Between Character Education and Democratic $\mathrm{Ci}$ tizenship Education. Journal of Research in Character Education, Vol. 6 No. 2, 2008, pp. 63-80; Muhammad Ayoob Sheikh and Zareen Abbassi, "Educational Approach to Character Building: A Paradigm Shift", Journal of Management and Social Sciences, Vol. 3 No. 2, Fall 2007, pp. 105-119.

2 M. Castells, 1999, Flows, Networks, and Identities: a Critical Theory of the informational Society, New York: Oxford University Press. the world and challenged the conventional approach to moral education. ${ }^{3}$

It will be advisable therefore not to stop the embedment directly after they accomplish their study at the elementary and intermediate grades. It needs to maintain the embedded values and sustained character building is a must. The reinforcement of embedded values remains needed to do for college students before they really engage in society even in fact it is needed all life long.

This paper, proposes the sustained character building for college students by means of literature. It aims particularly at exploring the reasons why literature could still serve as one of the effective media to establish sustained character building for college students, without ignoring the facts that they are relativelly more mature than those who are at junior and high schools and that they major in various disciplines. It will also explore what instructional strategies are appropriate to do so.

\section{Theoretical Frameworks}

Character building has been inviting the great concern for all in most countries. Seminars, conferences and summits on character building and character education have taken place anywhere regionally, nationally and even internationally with their own interest and emphasis. It has also been attracting lots of researchers to give their thoughts on the issue.

There are at least three enduring facts on the issue. First, character building is commonly identical to the embedment of certain core values perceived to be the basis of good character especially for children and adolescents. The core values may be principally the same around the world but the priority may vary in each country. There is some slight variation among researchers as to which specific traits constitute an ideal character education program. Lickona proposes responsibility, respect, tolerance,

W. Damon (ed), 2002, Bringing in a New Era in Character Education, Stanford CA: Hoover Institution Press. Retrieved 5 March 2017 from http://files.eric.ed.gov/ fulltext/ED476547.pdf 
prudence, self-discipline, helpfulness, compassion, cooperation, courage, honesty, fairness, and democratic values. ${ }^{4}$ In The United States of America a panel of 20 educators recommended caring, compassion, kindness, and empathy, citizenship, courage, fairness, honesty and trustworthiness, integrity, leadership, perseverance in establishing and attaining goals, respect, responsibility, and team work and cooperation. ${ }^{5}$ Ursula Mc Lackland, Regional Secretary General of UPF-Asia (2011) recommended Altruism as the organizing core virtue, from which all other virtues such as honesty, integrity, responsibility, respect, compassion, etc., ${ }^{6}$ emanate. Based on values derived from Pancasila, the five principles covering Belief in the One Supreme God, Humanity, Unity, Democracy and Social Justice, Indonesia decided 18 values to be prioritized as the objectives of Character Education for all strata of education. They are: religiousness, honesty, toleration, discipline, hard work, creativity, independence, democracy, curiosity, nationalism, patriotism, achievement oriented, friendship/communication, peacefulness, keen of reading, environmentally savvy, social care and responsibility. ${ }^{7}$

Second, there has been an enduring conviction that character building should be started at the young age and that if the embedment of the core values is done when a person is still young, it will last forever. Accordingly the ma-

T. Lickona, op.cit.

Gina M. Almerico, "Building character through literacy with children's literature", Higher Education Journal Vol. 26, October, 2014.

6 See in Lukas Pokorny, “A Feminising Revolution: The Unification Movement and the 'Age of Women'”, Interdisiplinary Journal for Religion and Transformation, 2007, p. 216

7 Faridah Alawiyah, "Kebijakan dan Pengembangan Pembangunan Karakter melalui Pendidikan di Indonesia", Aspirasi, Vol. 3, No. 1, 2012, p. 94-95. Retrieved 4 May 2017 from https://jurnal.dpr.go.id/index.php/aspirasi/article/view/259/200. See also E.H. Robinson III, K. Jones \& B. Hayes, "Humanistic Educaton to Character Education: An Ideological Journey", Journal of Humanistic Counseling, Education \& Development, Vol. 39 No. 1, 2000, pp. 21-25; Nurhasanah and Qathrin Nida, "Character Building of Students by Guidance and Counseling Teachers through Guidance and Counseling Services", Jurnal Ilmiah Peuradeun, Vol. 4 No. 1, January 2016, pp. 65-75; Sri Rejeki, "Pengembangan Karakter Melalui Pelayanan Bimbingan dan Konseling", Majalah Ilmiah Pawiyatan, Vol. XX No. 3, 2013, pp. 47-57. jority of existing studies and researches focus their attention to the embedment of good virtues to children and adolescents as students at elementary and intermediate grades. There has been not much consideration to think of the education of character for college students. Among those few figures who have thought of character building for college student is Anne Colby. She fought for reestablishing student morality and character as targets of higher education's central mission. She pointed out that higher education has drifted toward increasing specialization and compartmentalization. Those who would recapture the old ground have met with great resistance. She argued that students' values, moral and civic assumptions, and identities are shaped in college. It is time to be more self-conscious and intentional about this, and to think carefully about the particular framing of goals and strategies that are appropriate and feasible within a given institution. ${ }^{8}$

Third, while they start considering the integrated program involving society and government, they still regard schools and families as the main determinants in building the good character of the youth. Steje asserts

"Educators and communities often recognize the value of character education, but feel a lack of confidence in knowing how to implement a formal program. However, when community and school leaders collaborate and make character education and staff training a priority, significant benefits can occur that can impact generations." 9

Family was the center and the internalization of core values done at home. The establishment of public schools relatively reduced their duty but not their responsibility. Lots of scholars share the common idea. Schools are consi-

8 W. Damon (ed), op.cit, p. xx. See also Marlene Scardamalia and Carl Bereiter, "Higher Levels of Agency for Children in Knowledge Building: A Challenge for the Design of New Knowledge Media", The Journal of The Learning Sciences, Vol. 1 No. 1, 1991, pp. 37-68. See also Syamsu A. Kamaruddin, "Character Education and Students Social Behavior", Journal of Education and Learning, Vol. 6 No. 4, 2012, pp. 223-230

9 B.L. Steje, 2010, Nuts and Bolts of Character Education: A Literary Review, p. 5. Retrieved 5 March 2017 from http://strata.vaesite.com/_data/uploads/files/ CharacterEducationReport.pdf 
dered to be the appropriate places to educate good character. ${ }^{10}$ Schools with successful character education programs reported less absenteeism, fewer discipline problems, decreased referrals for misbehavior, a lower dropout rate, and higher performance scores on standardized achievement tests. ${ }^{11}$ Schools have an important role to play in the development of children's social and emotional growth. Educators must find ways to infuse the curriculum with character building. ${ }^{12}$ By societal demand and throughout history it is believed that character education needs to be consciously taught in public schools to intentionally shape student's core values throughout the existing curriculum. ${ }^{13}$ However parents' guidance is still needed. Parents and teachers are encouraged to go hand in hand as the main determining educators for their children and pupils. ${ }^{14}$

In this respect, The Government of Indonesia puts character building as one of the main priorities in National Development. In Buku Induk Kebijakan Nasional Pembangunan Karakter Bangsa 2010-2025 (2010) a sustainable na-

10 Lawrence Kohlberg and Richard H. Hersh, "Moral Development: A Review of the Theory", Theory in Practice Vol. 16, No. 2 April 1977, p. 53.

11 E. Wynne \& K. Ryan, 1997, Reclaiming our schools: Teaching character, academics, and discipline, Upper Saddle River, NJ: Prentice Hall. See also Jere Behrman and Nancy Birdsall “The Quality of Schooling: Quantity alone is Misleading". American Economic Review. Vol 73. 1983, pp. 928-946

12 S.L. Mc Elmeel, 2002, Character education: A book guide of teachers, librarians, and parents, Greenwood Village, CO: Teacher Ideas Press. See also Jere R. Behrman, David Ross, Richard Sabot, and Mathew Tropp "Improving the Quality Versus Increasing the Quantity of Schooling". Economics of Education Review. Vol 16, No. 2 1994, pp 127-142; Jere R. Behrman, Shahrukh Khan, David Ross and Richard Sabot. "School Quality and Cognitive Achievement Production: A Case Study for Rural Pakistan”. Economics of Education Review. Vol. 16, No. 2, 1997, pp 127-142; M. Booissiere, J. B. Knight and R. H. Sabot "Earning, Schooling, Ability and Cognitive Skills", American Economic Review. Vol 75, 1985, pp.1016-1030.

13 Margo O'Sullivan, "The Reconceptualisation of LearnerCentred Approaches: a Namibian Case Study", International Journal of Educational Development, Vol. 24, Issue 6, November 2004, pp 585-602.

14 S.L. Mc Elmeel, op.cit, Jamie Marshall, op.cit, Emily M. Fitz Simons, "Character Education: a Role for Literature in Cultivating Character Strengths". Master of Applied PositivePsychology (MAPP) Capstone Projects. Vol. 50, 2013. Retrieved 1 March, 2017 from http://repository. upenn.edu/mapp_capstone/50 tionnal policy on the development of character building through education is planned to be done in three phases. The first phase (2010-2014) is the phase for consolidation and implementation; the second phase (2015-2020) is the phase for reinforcement of strategy and implementation; and the third phase (2020-2025) is the time for sustainable development. The strategies taken are stream top down, stream bottom up, and stream revitalizes program (Panduan Pelaksanaan Pendidikan Karakter Kementerian Pendidikan Nasional, 2011). ${ }^{15}$

The promotion of character education at schools can occur in a variety of ways. Some make use of literature as one of the media. Literature is deemed to play a significant role in our lives and character development. In fact, literature has been regarded as one of the most effective media to embed such values in children's mind. ${ }^{16}$

Alamerica ${ }^{17}$ observes good literature with character development themes has the power to develop, shape, and reinforce dispositions essential for instilling in students important core ethical values. Creating character themed lessons that combine high quality appropriate children's literature with effective literacy instruction can be a daunting task. Teachers therefore are faced with the dilemma of finding books that will do double duty in teaching both character and literacy concepts. Fortunately The US Government and community have been

15 Compare this suggestion with Rokhman et.al., opinion in Fathur Rokhman, Ahmad Syaifudin, and Yuliati, "Character Education for Golden Generation 20145 (National Character Building for Indonesian Golden Years)", Procedia - Social and Behavioral Sciences, Vol. 141, 2014, pp. 1161-1165.

16 Joy Mosher, “Children's literature and Character Development, in The Forth and Fifth Rs: Respect and Responsibility”, Newsletter, Vol. 8, No. 1, 2001; William D. Edgington, "To Promote Character Education, Use Literature for Children and Adolescents", The Social Studies, May/June 2002; S. Brynildssen, 2002, Character Education through Children's Literature, Family Learning Association Bloomington IN. [ED 469 929], Retrieved 2 March 2017 from http://wik.ed.uiuc.edu/index. $\mathrm{php} /$; Jamie Marshall, op.cit,; T. Lintner, "Using "exceptional" children's literature to promote character education in elementary social studies classrooms. The Social Studies, Vol. 102, 2011; Emily M. Fitz Simons, op.cit; Gina M. Almerico, op.cit.

17 Gina M. Almerico, op.cit. 
providing great number of books designated to support character building for children and adolescents. However, he recognizes that the development of the character education program is still in progress. It has not been really worked yet in other countries, including in Indonesia.

\section{The Effectiveness of Literature}

Literature has been used over countless years to entertain, inform, engage, and evoke thought in the classroom. It has also been used by parents to internalize some core values to their young children before and after the coming of public schools. Children are believed to take after the given models. To provide much more intended examples, parents used to utilize children's stories to be the sources of the intended examples. Teachers do the same. Wei (1999) wrote that literature can also be used to help students deal with issues or problems they will inevitably encounter as they mature and grow. Topics such as dealing with grief, responding to bullying, overcoming fears, developing positive relationships, and understanding and appreciating differences are mostly found in children's stories. Similarly Fitz Simons asserts a role for literature in cultivating character strength. She argues that by cleverly capitalizing on the existing skills of regular classroom teachers all schools, regardless of their human and financial resources, location or demography, can begin embedding principles of positive psychology. ${ }^{18}$

In Malaysia literature is meant to be enjoyed, as literature can be employed as a tool to promote literacy and proficiency in the language. It assists students to deal with social, cultural, and racial problems. The CDC of Malay-sia Ministry of Education (2006) provides three benefits of having children's literature in the primary schools. First, the personal and emotional gains that offer enjoyment enriches children understanding of themselves and the world around them, develop imagination, help children make sense of their own experience

18 Emily M. Fitz Simons, op.cit, p. 2 and evoke one's feelings on issues related to life. Second, the learning allows children to learn new ideas and gain new knowledge such as cultural traditions, values, and real life issues. This will allow children to develop respect for themselves and others, and will encourage them to become aware of their audience. Third, the language gains would help children to develop an awareness of how language works in communication; to develop an understanding of the meaning of words; to allow them to experience new way of using language that bridges the gap between written and spoken language and to allow them to experience in the form of narratives. ${ }^{19}$

A nonprofit organization of Literature for All of Us in Chicago and Evanston was established in 1996. It has been helping young people realize their strengths through literature as well as engaging them in reading groups where they get the opportunity to discuss poetry and literature. They use an innovative book group model to build communities of readers, writers and critical thinkers in underserved communities. They use reading, writing, and discussion to explore their strengths and share their ideas, while experiencing a sense of accomplishment, self-esteem and hope. Their famous slogan is "We open worlds by opening books!" (http:// www.literatureforallofu). Literature is still effective to maintain and reinforce the embedded values for college students from different disciplines due to its natural characteristic, its wide spectrum, and its dynamically broaden functions; and the choice of particular literary theory.

\section{Natural Characteristics of Literature}

Despite the acknowledgment of its essential role in transmitting important core values useful for the formation of good character, literature is still underestimated and perceived to be created without any seriuos purpose. Kooistra and Schutt point out that even if there

19 S.S. Mustakim, R. Mustapha, \& O. Lebar, "Critical Analysis of Supportive and Supressive Factors for the Children's Literature program in Malaysia", Journal of Education and Learning, Vol. 9, No.1, 2015, p. 3. 
is a purpose in the creation of literary works, the aim of the writers is fundamentally the same. They try to amuse their readers by means of fictitious story. Entertaining becomes the marking characteristic of literature. ${ }^{20}$ This may be true especially for those catagorized to what so-called popular literature. This characteristics, however turns out to be of significance in dealing with its role as the medium of the reinforcement of embedded values for college students. Works of literature serve as a pleasant and momentary escape from the boringness and burden of study. The provision of "light" works while containing the given serious challenging issues would not be perceived as a serious duty. The reinforcement of embedded core values would run more pleasantly because even if they are aware of the purpose they would not feel to be nurtured by the instructors.It is the works which teach and educate them and it would not hurt their ego.

Literature is always up-to-date. Horton and Edwards ${ }^{21}$ state that "literature tends to reflect the dominant tendencies of its era and to grow out of the moral, social, and intellectual ferment impinging upon the sensibilities of literary men. "Accordingly, it always changes in accordance with the era. The themes presented are always in accordance with the development of the era and the condition of the society at the time. Themes of cybercrimes, for instance would not be found in the works written before the invention of internet. The lives of the queers would not be explicitly seen in the works written before 1970s. This characteristics makes it possible for works of literature to provide various topical materials of the given values which have been embedding since they were young. It will attract the dynamic discussion amongst advanced grade students because the values presented in the works written in one era may be different from those of other era, the recent era may not have values the sa-

20 J. Kooistra and J.H. Schutt, 1937, A Shorter Introduction to English Literature, Groningen: Wolters.

21 R.W. Horton, and W.H. Edward, 1974, Background of American Literary Thought. New Jersey: Prentice-Hall, Inc., p. 1-2 me as the embedded ones obtained while they were still young. This will encourage them to compare and find out the reasons of possibly differences and thus developing their care and sharpening their ability to make right decision.

Literature is universal. The universality of its appeal at any given time and the biding character of the appeal, at its highest, is not only for succeeding ages but for succeeding civilization. ${ }^{22}$ Universal major themes such as love, responsibility, respect and honesty will be found in works of literature from all over the world. The difference lies on the concept resulted from concensus among the members. The universal nature of literature provides much more possibilities to make use of literary works from any countries. If they could not find the appropriate works containing the intended values, they may make use of literary works from other countries even the translated ones. In this respect, there is a great possibility for Indonesia to take this chance as there are abundant number of translated literary works in amost all book stores in Indonesia. College students are relativelly mature enaugh not to be easily influenced. The taking of works from other countries containing the same issues will encourage them to do comparison of the concept of the given values without feeling afraid of being contaminated as well as intimidated by foreign values; and thus enriching, widening and reinforcing their own character.

Literature has evolved and is still evolving. ${ }^{23}$ Arthur Krystal said that apparently, "literary means not only what is written but what is voiced, what is expressed, what is invented, in whatever form" - in which case maps, sermons, comic strips, cartoons, speeches, photographs, movies, war memorials, and music all huddle beneath the literary umbrella. Books

22 E. Albee, "The Meaning of Literature for Philosophy", The International Journal of Ethics, 1909, Retrieved 6 March 2017 from https://www.jstor.org/stable/pdf/ 2376972.pdf

23 Natalie Ward, “Iser's Aesthetic Response Theory Viewed in the Context of Collaborative Hyperfictions", CUREJ College Undergraduate Research Electronic Journal, 2006, Retrieved 4 March, 2017 from http://repository. upenn.edu/curej/42. 
continue to matter, of course, but not in the way that earlier generations took for granted (para 1). The use of computer technology, particularly the internet has given rise to new categories of literary works. Nowadays literature works cover not only oral and printed literary texts, but also digital literary texts which are popular as hypertexts. The idea of presenting information in interactive, useful ways that reflected reality and associations between ideas gave rise to the modern hypertext. ${ }^{24}$

Nowadays hypertext fictions can be separated into three categories, which reflect the varying degrees of control the reader has over the narrative. The first type is very similar to the format found in traditional linear literature, in which the reader has very limited control over the narrative, with all readers reaching the same conclusion of the story. The second type of hypertext fiction enables the reader to contribute to the text and save their contributions for later viewing. The features of this type of hypertext allow the opportunity for more storylines to be explored. The third category consists of ongoing stories with many authors contributing to the narrative. "With this format, the readers are even more empowered to contribute to the story at any time. The contribution may be temporary, or it may become a permanent part of the story". Therefore, such stories are perpetually evolving and defy all typical literary conventions. ${ }^{25}$

The last type would be challenging for college students. The nature of writing and reading any digital text encourages freedom of thought and does not demand that any particular conventions be followed at any point of either the reading or writing process. ${ }^{26}$ When digital texts are presented in the form of collaborative hyper fictions, there is no singular author but rather an unlimited number of con-

\footnotetext{
24 A. Kristal, "What is Literature: In defense of the canon", Harper Magazine, March 2014, Retrieved 5 March 2017 from http://archive.harpers.org/2014/03/pdf/Har persMagazine-2014-03-0084827.pdf?AWSAccessKeyld= AKIAJXATU3VRJAAA66RA\&Expires $=1488725763 \&$ Signatur e $=z \% 2 F p M l u E B S G k p O R e O t v P w r 2 M n G M 4 \% 3 D$

25 Natalie Ward, op.cit. p. 26

26 Ibid, p. 6
}

tributing authors. In this way, the notions of individuality surrounding the authorship of printed texts are discarded in favor of a more communal approach to authorship and creative property. Involving in this type of fictions will remind the students of communal sense and at the same time strengthens their creativity value.

\section{The Wide Spectrum of Literature}

Literature grasps the whole aspect of life. It does not limit itself to certain fields. The material of literature may come from the imagination of the authors but undoubtedly it derives from their physical interaction with society or at least from their observation of their physical surrounding and social environment. Mimetic theories of literature show that literature is regarded not only as the reflection of the universe but also as a lamp which will enlighten the readers. ${ }^{27}$ Michael Zeraffe (1973) asserts that there is an interrelationship among works of art, society and history. The form and the content of the novel derive more closely from social phenomenon, and they seem to bound up with particular moments in the history of the society. Furthermore he asserts that the novel is directly concerned with the nature of the situation in history; and with the direction confronts us openly with the issue of the meaning and value of our ineluctable historical and social condition. Meanwhile Horton and Edwards state that literature tend to reflect the dominant tendencies of its era and to grow out of the moral, social, and intellectual ferment impinging upon the sensibilities of literary men. ${ }^{28}$ Novelists, according to Nelson Mandred Blake "witness to history." He argues that conventional document like reports, speeches, treaties, proclamation, orders, messages and statues are not enough. "To be able to get through understanding of our history we need to rely upon

\footnotetext{
27 MH. Abrams, 1958, The Mirror and the Lamp: Romantic Theory and the Critical Tradition, London: Oxford University Press.

28 R.W. Horton, and W.H. Edward, loc.cit.
} 
literary works." 29 All leads to the idea of connecting literature to other fields of studies.

Infact, literature contains various issues from various fields that it invites and encouages interdisciplinary approach. Literature has been connected to other fields. Albee asserts that all arts are inevitable interpretations of $\mathrm{li}$ fe and as interpretations they are of equal importance. Literature, again, is not a collection of more or less naive theories of life, which it is the business of the philosopher to dissect and then put together again in terms of his own technical system; it is the most direct, the most inevitable, the most vital interpretation of life itself. Albee further explains that the potential immortality of the very greatest works of literature rests upon anything but a material basis; it is due to the fact that they seem likely to make a more lasting appeal than anything else whatever to what is most fundamental in that mysterious complex which we call human nature. ${ }^{30}$

Law has been in Literature for ages but it was not until the first half of the twentieth century that scholars in Western countries began to explore it more seriously. Literature and Law movement comes into being as the response of the isolation of law from other disciplines and the idea of humanizing law to have optimal function for the betterment of social order. In its early stages, the movement focused strictlyon the law inliterature; however, beginning in the late 1970s the law as literature perspective began to gain its popularity. The law in literaturemovementis the study of representations of thelegal order in fiction usually novels and plays. ${ }^{31}$

29 Nelson Mandred Blake, 1969, The Road to Reno: A History of American Divorce, New York: Macmillan, p. 1-2. See also Robert S. Pickett, "Clio: The Missing Muse in Family Life Education", The Family Coordinator, Vol. 18 No. 1 , January 1969, pp. 27-31.

$30 \quad$ E. Albee, op.cit, p. 7

31 Dunlop in T. Hariyanti, "The contribution of Literature to the Humanization of Law in Indonesia", Jurnal Humaniora, Vol. 25, No. 2, 2013, pp. 117-128. Retrieved 2 January 2017 from https://journal.ugm.ac.id/jurnalhumaniora/article/view/2355 oai: doaj.org/article:2d8 28e35b0ac49be92416c8f3e576fd7
Similarly religion has been in literature for a long time, but it was not until the late twentieth and early twenty-first centuries that people began to get more interested in connecting them. It is triggered by the great concern from both sides of the greater impact of secularization. Toroczkai \& Preda pointed out that T.S. Eliot has emphasized the need to analyze a work of fiction not only linguistically but also ethically and religiously. "Even the novel that does not directly concern religious themes concerns relevant theological motifs and, therefore, the analysis of the great works of the world literature must become a part of the theology today". 32

The wide spectrum of literature makes it possible to provide various topics of discussion in accordance to the discipline of the students. Students of Law and Psychology may make use of the works of John Grisham which mostly deal with the crimes and the ethics of lawyers. Historical literature may be used by student of politics and history; scientific literature may be used by students of science, and theology. In fact, a single work of literature sometimes can be discussed by students from various disciplines.

\section{The Dynamic Function of Literature}

The function of literature develops dynamically. It does not go stright but move upwards and backwards depending on the era and the interests of the creators, the users and often those who arein power. ${ }^{33}$ Principally literature has two main functions: to give pleasure and provide a means to an end, to get things done. The implementations of the second function vary depending on the given perspectives. From the social perspective as observed by Paul

32 Ciprian Iulian Toroczkai and Daniela Preda, "Religion and Literature Case Study - Mythanalysis", European Journal of Science and Theology, Vol. 10 No. 1, February 2014, pp. 125-132.

33 T. Hariyanti, "The Challenges of World Wide Web in Teaching and Learning English Literature in Indonesia", Arab World English Journal, Vol. 6, No. 3, 2015, 261274. (SSRN Scholarly Paper No. ID 2834742). Rochester, NY: Social Science Research Network. Retrieved from http: / / papers.ssrn.com/abstract $=2834742$ 
Chiariello there has been a range of research that literature affects our psychology and shapes three most fundamental social functions: (1) literature is simply to create a reference point for discussions, (2) literature helps us relate to others in an I-You relationship as well as more accurately interpret others' mental states, (2) literature often gives us keen insights into another's world, allowing us to get brief glimpses through unfamiliar eyes. These functions offer the students with manifold opportunities for raising awareness of difference and for developing tolerance and understanding. ${ }^{34}$

The referential function might be accepted passively because referring to Kuenzli literature supports, restates and reinforces the dominant cultural system and its values. It might be used as the justification of what they have already had or believed. In fact this is the main reason of using lierature as a means to build the character of children and adolescentsin many countries. The norm-fulfilling function of literature encourages the product of "good literature" which is mostly deemed to be appropriate for such effort. ${ }^{35}$

The referential function might invite active debate because despite its norm-fulfilling function, literature has norm-breaking functions. ${ }^{36}$ Literature sometimes contains values that violate and break the familiar social norms and codes. At best it helps develop other virtues and broaden the reader's mind because it opens windows to challenging values different from their own. In other words it will provide rich sources for comparison. At worst instead of reinforcing the embedded values, it will make the reader confused and weaken the embedded values. This may be true for children and adolescents. But it would be challenging for college students. It is advisable, therefore, that the given literary works containing, elaborating and particularly questioning or challenging the

34 Paul Chiariello, "Why is Literature Important? The 3 Social Functions of Fiction", Applied Sentience, 2014, Retrieved 10 March 2017 from https://appliedsentience. com/2014/05/06/why-is-literature-important-the-4social-uses-of-fiction/

35 T. Hariyanti, loc.cit.

36 Ibid. given embedded values are taken to be the source. In Indonesia, Bellenggu (1953) by Armyn Pane, LayarTerkembang (1937 by Sutan Takdir Alisyahbana, and Atheis (1949) by Akhdiat K. Mihardja could be used tochallenge the decison making in the value of traditionalism vs. modernisn.

The ideological and political function of Literature are seen in its utilization by those who are in power. Canonization is one of examples of such functions. Historically in nineteenth century England, literature emerged as an extremely important idea, a special kind of writing charged with several functions. Made a subject of the British Empire was charged with giving the natives an appreciation of the greatness of England and engaging the ungrategul participants in a historic civilizing enterprise the earlier period of English literature. Similarly at the Early National Period, American and Indonesian literature were used to encourage and strengthen a sense of the importance of republican institution and to reflect the desire for national literature.

Similarly as observed by Pujiharto in the era of Balai Pustaka, Indonesian literature was directed to fulfill the interest of the Dutch Colonial to keep maintaining their power over their colony:

The Dutch colonial government made a very systematic effort by creating a certain discourse in the course of exaggerating and glorifying colonial culture and even the colonization practice that they had done. They exploited literary works created by natives by turning them in such ways that the story line went in the direction they wanted. ${ }^{37}$

Pujiharto also pointed out that contemporary research studies done by researchers of Indonesian literature by using a post-colonial perspective indicates that early Indonesian literary works like Siti Nurbaya by Marah Rusli (1922) and Salah Asuhan by Abdul Muis (1928) portray the operation of the colonial ideology

37 Pujiharto, "Reorientation of Literary Study: From Indonesian Literature to Literature in Indonesia", Mediterranean Journal of Social Sciences, Vol. 7, No.1, 2016, p. 293. DOI: $10.5901 / \mathrm{mjss} .2016 . v 7 n 3 p 288$ 
in its effort to keep maintaining its grip on the natives. Instead of portraying anti-colonial attitudes, such novels portray identity crisis and praise for colonialism. Burung-Burung Manyar (1981) by Y.B. Mangunwijaya which was written in pasca colonialism era presents the same crisis. Taking stories produced in those ears may reinforce and challenge the imbedded values of nationalism and patriotism.

The religious function of Literature fluctuates. According to Parker originally, religion penetrated every activity; now, by contrast, it has been removed from one after another of the major human pursuits under complete secular control. When secularism gains its utmost power, and when there is a great tendency that a religious view of life is simply one option amongst others people begin to reconsider the religious function of literature. Harries states:

... in a time of unbelief, it is from literature, from novels, poetry and plays for example, that people derive insights that in previous ages they might have gained from the Bible and those one or two hour sermons, that were often the norm. Approaching the matter from the other end, as it were, because the Bible and sermons are for so many a great switch off, it is when the great Christian truths are expressed in or related to the imaginative world of literature, that not only are our defensive barriers breached, but we can see something of the real depth and richness of Christian truth. ${ }^{38}$

To be sure, there are some literary works still in the service of religion despite its relative small proportion.

\section{Planning Activities}

Designated as a sustainable lifelong effort, this program aims at reinforcing the given imbedded values without requiring fixed results at the end of their study. It is emphasized that

38 Parker and Harries in T. Hariyanti \& D. Nurhayati, "Pearl in Hawthorne's the Scarlet Letter: a Socio-Religious Perspective", Arab World English Journal for Translation \& Literary Studies, Vol. 1, No.1, 2017, p. 67-68, Retrieved 6 March 2017 DOI: http://dx.doi.org/ $10.24093 /$ awejtls/vol 1no1.5 lecturers are not to moralize and that student should clarify his or her values

\section{Instructional Strategies}

There are at least 5 appropriate strategies in reinforcing character building for college students.

Discussion: For students majoring in literature and language art the discussion could be inherently held in classrooms on the given subjects already designated in their curriculum as their specification or in an extra activity designed particularly to discuss certain challenging issues. But for those majoring in other discipline of studies in which there is not subject on literature in their curriculum, the reinforcement of embedded values can be done in extra activities designed particularly to discuss challenging issues found in works of literature.

Debate: Debating can be employed as an instructional strategy wherever the learning material and circumstances are open to opposing points of view. It offers training in argumentation and encourages mature judgment. Debaters learn the value of suspending judgment until both sides are scrutinized, learn appropriate manners and proper behavior in diverse situations; and at the same time it will develop student's courage to stand up and defend their position.

Seminar: It can be done by the student themselves. In turn they become the presenters on certain topics dealing with the given core values. It is also possible to invite the guest speakers such authors or scholars of literature.

Film Appreciation: Film is one of the forms of literature and sometimes films are based on novels. Appreciating Film might be employed as an interesting strategy especially for Students who do not major in literature.

Creative Writing: Hypertext fictions might be used as the source of material and instructional 
strategy as well. Playing creatively with hypertexts-changing old stories and helping create new ones-can be an enthralling activity. In this respect lecturers might use the model of collaborative hyper fictions as the strategy. Students are encouraged to expand or change the existing stories containing the chosen character traits in accordance with their values.

\section{Materials}

The works taken are especially those containing, elaborating and challenging the familiar embedded values. Instructors may provide any genre of literature covering not only great and serious works but also those which categorized as popular ones for students majoring in language and literature. For those majoring in other disciplines; however it is advisable to take the lighter ones. Poems, Short stories and films are preferable to evoke the dynamic discussion.

The following works might be worth considering as the sources. It is possible to find some character traits in a single work: Atheis (Ahdiat K. Mihardja); Anne Bradstreet's poems; Belenggu (Armyn Pane); Burung-Burung Manyar (Y.B. Mangunwijaya); Chairil Anwar's works; Fire and Ice (Robert Frost); Habiburrahman El Shirazy's novels; Harry Porter (J. K. Rowling); Joy and Peace in Believing (John Newton); John Grisham's works; Kubah (Ahmad Tohari); Laskar Pelangi (Andrea Hirata); Salah Asuhan (Abdul Muis); Siti Nurbaya (Marah Rusli); Sutasoma (Cok Sawitri); Taufiq Ismail's poem; The Scarlet Letter (Nathaniel Hawthorne); The Outsiders (S.E. Hinton); and The Great Gatzby (F. Scott Fitzgerald).

\section{Conclusion}

Technology advancement results in the great changing in almost all aspect of life. The shift of values happens inevitably. Character building which is commonly identical to the embedment of core values perceived to be the basis of good character therefore becomes a sustained lifelong effort. It should not be stopped directly after children and adolescents accomplished their study. It should be maintained while they are studying and even after they really engage in real life. The use of literature to sustain character building for college students is worth trying.

The entertaining and always updating as its natural characteristics will enable works of literature to provide various topical materials of the given values which have been embedding since they were young to attract the dynamic discussion amongst advanced grade students from any fields of studies without feeling ignored and under the nurture of the instructors. The universal nature of literature provides much more possibilities to make use of literary works from any countries without being contaminated as well as intimidated by foreign values, instead gaining much more resources for comparison and thus enriching, widening and reinforcing their own character. The wide spectrum of literature covering all aspect of life makes it possible to be applied interdisciplinarily. The dynamically broaden functions of literature ranging from norm-fulfilling to normbreaking and covering variety of perspectives enable it to widden the horizon and develop the dynamics of sustained character building;at the same time it makes it more challenging and acceptable for all fields of studies.

The instructional strategies which are deemed to be appropriate for college students are those which are familiar with the life of mature students such as discussion, debate, seminar, Film appreciation and creative writing by making use of the model of collaborate hypertext fictions.

\section{Reference}

Abrams, MH. 1958. The Mirror and the Lamp: Romantic Theory and the Critical Tradition. London: Oxford University Press;

Alawiyah, Faridah. "Kebijakan dan Pengembangan Pembangunan Karakter melalui Pendidikan di Indonesia". Aspirasi, Vol. 3, No. 1, 2012, pp. 87-101. Retrieved 4 May 2017 from https://jurnal.dpr.go.id/index. php/aspirasi/article/view/259/20;

Albee. E. "The Meaning of Literature for Philosophy". The International Journal of Ethics, 1909. Retrieved 6 March 2017 from 
https://www.jstor.org/stable/pdf/23769 72.pdf;

Almerico, Gina M. "Building Character through Literacy with Children's Literature". Higher Education Journal, Vol. 26 October, 2014;

Behrman, Jere R. and Nancy Birdsall "The Quality of Schooling: Quantity alone is Misleading". American Economic Review. Vol 73. 1983, pp. 928-946;

Behrman, Jere R. David Ross, Richard Sabot, and Mathew Tropp. "Improving the Quality Versus Increasing the Quantity of Schooling". Economics of Education Review. Vol 16, No. 2 1994, pp 127-142;

Behrman, Jere. R., Shahrukh Khan, David Ross and Richard Sabot. "School Quality and Cognitive Achievement Production: A Case Study for Rural Pakistan". Economics of Education Review. Vol 16, No. 2, 1997, pp 127-142.

Blake, Nelson Mandred. 1969. The Road to Reno: A History of American Divorce. New York: Macmillan;

Booissiere, M.; J. B. Knight and R. H. Sabot. "Earning, Schooling, Ability and Cognitive Skills", American Economic Review. Vol 75, 1985, pp.1016-1030;

Brynildssen, S. 2002. Character Education through Children'sLiterature. Family Learning Association Bloomington IN. Retrieved 2 March 2017 from http://wik.ed.uiuc. edu/index.php/;

Castells, M. 1999. Flows, Networks, and Identities: a Critical Theory of the Informational Society. New York: Oxford University Press;

Chiariello, Paul. "Why is Literature Important? The 3 Social Functions of Fiction". Applied Sentience, 2014. Retrieved 10 March 2017 from https://appliedsentience. com/2014/05/06/why-is-literatureimportant-the-4-social-uses-of-fiction/;

Damon, W. (ed). 2002. Bringing in a New Era in Character Education. Stanford. CA: Hoover Institution Press. Retrieved 5 March 2017 from http://files.eric.ed.gov/fulltext/ED476547.pdf;

Edgington, William D. "To Promote Character Education, Use Literature for Children and Adolescents". The Social Studies. May/June 2002, pp. 113-116.
Hariyanti, T \& D. Nurhayati. "Pearl in Hawthorne's the Scarlet Letter: a Socio-Religious Perspective". Arab World English Journal for Translation \& Literary Studies, Vol. 1, No.1, 2017, pp. 65-78. Retrieved 6 March 2017. DOI: http://dx.doi.org/10.240 93/awejtls/vol1no1.5;

Hariyanti, T. "The Challenges of World Wide Web in Teaching and Learning English Literature in Indonesia". Arab World English Journal, Vol. 6, No.3, 2015, pp. 261274. Retrieved from http://papers.ssrn. com/abstract $=2834742$;

Hariyanti, T. "The Contribution of Literature to the Humanization of Law in Indonesia. Jurnal Humaniora, Vol. 25, No. 2, 2013, pp. 117-128. Retrieved 2 January 2017 from https://journal.ugm.ac.id/jurnalhumaniora/article/view/2355, oai: doaj. org/article:2d828e35b0ac49be92416c8f3e $576 f d 7$

Horton, R.W. and W.H. Edward, 1974. Background of American Literary Thought. New Jersey: Prentice-Hall, Inc.

Kamaruddin, Syamsu A. "Character Education and Students Social Behavior". Journal of Education and Learning, Vol. 6 No. 4, 2012, pp. 223-230;

Kohlberg, Lawrence and Richard H. Hersh. "Moral Development: A Review of the Theory". Theory in Practice, Vol. 16 No. 2 April 1977;

Kooistra, J. and J.H. Schutt. 1937. A Shorter Introduction to English Literature, Groningen: Wolters;

Kristal, A. "What is Literature: in Defense of the Canon". Harper Magazine, March 2014. Retrieved 5 March 2017 from http://archive.harpers.org/2014/03/pdf/ HarpersMagazine-2014-03-0084827.pdf? AWSAccessKeyId=AKIAJXATU3VRJAAA66R A\&Expires $=1488725763 \&$ Signature $=z \% 2 \mathrm{Fp}$ MluEBSGkpOReOtvPwr2MnGM4\%3D;

Lickona, T. 1991. Educating for Character: How Our Schools can Teach Respect and Responsibility. New York: Bantam Books;

Lintner, T. “Using “Exceptional” Children's Literature to Promote Character Education in Elementary Social Studies Classrooms". The Social Studies 102, 2011, pp 200-213;

Marshall, Jamie. 2006. Character Education Instruction Integrated Through Literature in Elementary Classrooms. All Regis Univer- 
sity Theses. Paper 408. Retrieved on 27 February, 2017 from http://epublications.regis.edu/theses;

Mc Elmeel, S.L. 2002. Character Education: a Book Guide of Teachers, Librarians, and Parents. Greenwood Village, CO: Teacher Ideas Press;

Mosher, Joy. "Children"s literature and Character Development, in The Forth and Fifth Rs: Respect and Responsibility", Newsletter.Vol. 8, No. 1, 2001, pp. 1-6;

Mustakim, S.S,.; R. Mustapha \& O. Lebar, “Critical Analysis of Supportive and Supressive Factors for the Children's Literature program in Malaysia". Journal of Education and Learning, Vol. 9, No.1, 2015, pp. 1-10;

Nurhasanah and Qathrin Nida. "Character Building of Students by Guidance and Counseling Teachers through Guidance and Counseling Services". Jurnal IImiah Peuradeun, Vol 4 No. 1, January 2016, pp 6575;

O'Sullivan, Margo. “The Reconceptualisation of Learner-Centred Approaches: a Namibian Case Study". International Journal of Educational Development, Vol. 24, Issue 6, November 2004, pp 585-602;

Parker, Dewitt H. 2003. The Principles Of Aesthetics: Chapter XV - The Function of Art: Art and Religion. Hypertext conversion by Philipp Lenssen. Retrieved 10 March 2017 from http://www.authorama.com/principles-of-aesthetics-16.html;

Pemerintah Republik Indonesia. 2010. Kebijakan Nasional Pembangunan Karakter Bangsa Tahun 2010-2025. Jakarta: Pusat Kurikulum Balitbang Kemdiknas;

Pickett, Robert S. "Clio: The Missing Muse in Family Life Education". The Family Coordinator, Vol. 18 No. 1, January 1969, pp. 27-31.

Pokorny, Lukas. "A Feminising Revolution: The Unification Movement and the "Age of Women'”. Interdisiplinary Journal for Religion and Transformation, 2007, pp. 214-234. DOI 10.14220/jrat.2017.3.2.214;

Pujiharto. "Reorientation of Literary Study: From Indonesian Literature to Literature in Indonesia". Mediterranean Journal of Social Sciences, Vol. 7, No.1, 2016, pp. 288-295. DOI: $10.5901 / \mathrm{mjss} .2016 . v 7 n 3 p-$ 288;
Rejeki, Sri. "Pengembangan Karakter Melalui Pelayanan Bimbingan dan Konseling". Majalah Ilmiah Pawiyatan, Vol. XX No. 3, 2013, pp. 47-57;

Robinson III, E.H.; K. Jones \& B. Hayes, "Humanistic Educaton to Character Education: An Ideological Jurney". Journal of Humanistic Counseling, Education \& Development, Vol. 39 No. 1, 2000, pp. 21-25;

Rokhman, Fathur.; Ahmad Syaifudin, and Yuliati, "Character Education for Golden Generation 20145 (National Character Building for Indonesian Golden Years)", Procedia - Social and Behavioral Sciences, Vol. 141, 2014, pp. 1161-1165;

Scardamalia, Marlene and Carl Bereiter. "Higher Levels of Agency for Children in Knowledge Building: A Challenge for the Design of New Knowledge Media", The Journal of The Learning Sciences, Vol. 1 No. 1, 1991, pp. 37-68;

Sheikh, Muhammad Ayoob.; and Zareen Abbassi, "Educational Approach to Character Building: A Paradigm Shift", Journal of Management and Social Sciences, Vol. 3 No. 2, Fall 2007, pp. 105-119;

Simons, Emily M. Fitz, 2013. Character Education: A Role for Literature in Cultivating Character Strengths. Master of Applied Positive Psychology (MAPP) Capstone Projects. 50. Retrieved $1 \mathrm{March}, 2017$ from http://repository.upenn.edu/mapp_caps tone/50;

Steje, B.L. 2010. Nuts and Bolts of Character Education: A Literary Review, Retrieved 5 March 2017 fromhttp://strata.vaesite. com/_data/uploads/files/CharacterEdu cationReport.pdf;

T. Lickona, "A Comprehensive Approach to Character Building in Catholic Schools", Catholic Education: A Hournal of Inquiry and Practice, Vol. 1 Issue 2, July 2013;

Toroczkai, Ciprian lulian. and Daniela Preda, "Religion and Literature Case StudyMyth-analysis", European Journal of Science and Theology, Vol. 10 No. 1, February 2014, pp. 125-132;

Ward, Natalie. "Iser's Aesthetic Response Theory Viewedin the Context of Collaborative Hyperfictions". CUREJ-College Undergraduate Research Electronic Journal, 2006. Retrieved 4 March, 2017 from http:// repository.upenn.edu/curej/42; 
122 Jurnal Dinamika Hukum

Vol. 18 No. 1, January 2018

Washington, E. Y.; M.A. Clark, and Dixon, A.L.. "Everyone in School Should Be Involved" Preservice Counselors' Perceptions of Democracy and the Connections Between Character Education and Democratic Citizenship Education". Journal of Research in Character Education, Vol. 6 No. 2, 2008, pp. 63-80;

Wynne, E \& K. Ryan, 1997. Reclaiming Our Schools: Teaching Character, Academics, and Discipline. Upper Saddle River, NJ: Prentice Hall. 